\title{
Interspecific competition
}

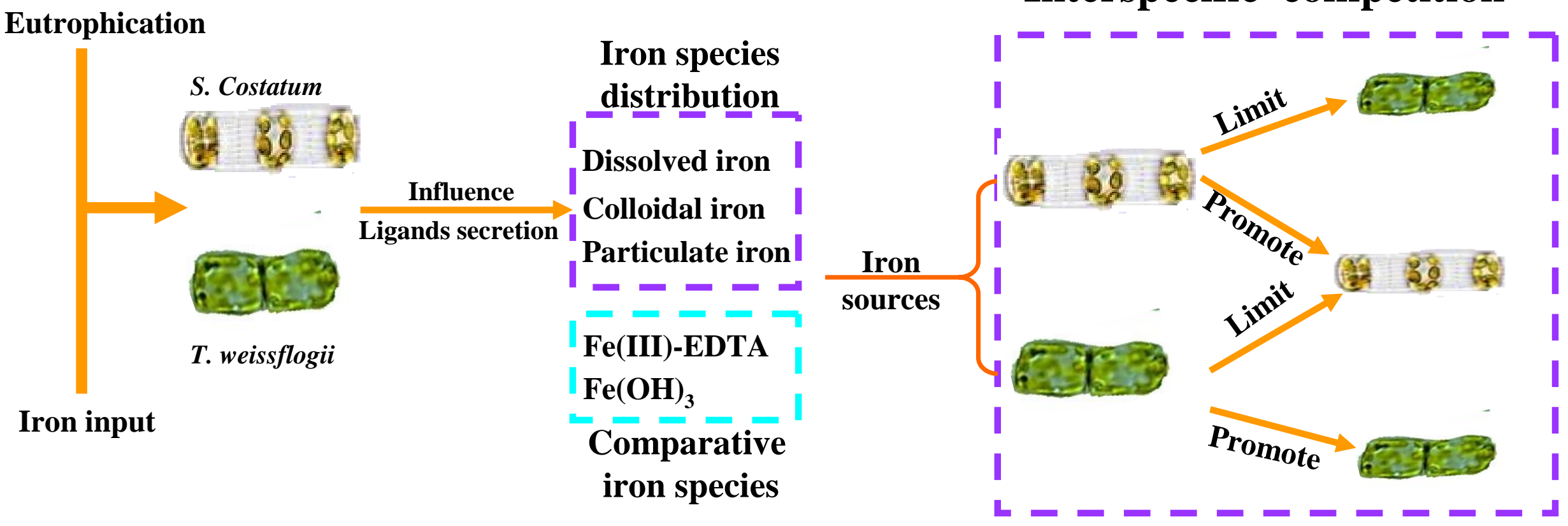

Bioavailability degree : dissolved iron from own exudates $>$ colloidal iron from own exudates > particulate iron from own exudates $>$ particulate iron from another algal exudates $>$ colloidal iron from another algal exudates $>$ dissolved iron from another algal exudates $>\mathrm{Fe}(\mathrm{III})$-EDTA $>\mathrm{Fe}(\mathrm{OH})_{3}$. 